\title{
The Importance of Location, Promotion, and Merchandising in Affecting the Consumer Purchasing Decision: A Case Study in PT Wijaya Motor Bandung, Indonesia
}

\author{
Dadang Suhairi \\ STAI Sabili Bandung, Indonesia \\ Email: dadangsuhairi@staisabili.ac.id
}

\begin{abstract}
The purpose of this study was to determine the effect of location, promotion and merchandising on consumer purchasing decisions at PT Wijaya Motor Bandung, Indonesia. This research method uses a quantitative approach. The data collected in this study used the distribution of questionnaires to 118 consumers at PT Wijaya Motor Bandung using a simple random sampling technique. The results of this study indicate that there is a positive and significant effect both partially and simultaneously between location, promotion and merchandising on consumer purchasing decisions at PT Wijaya Motor Bandung, Indonesia.
\end{abstract}

Keywords: Marketing, Location, Promotion, Merchandising, Purchasing Decisions

\section{A. INTRODUCTION}

The great impact caused by the flow of information technology in accelerating the process of transition to civilization, which is supported by the swift flow of information forces people to have the ability and extensive knowledge to compensate. The progress of human civilization brings humans into increasingly complex social dynamics. Bringing and forcing humans to face increasingly diverse life choices. Not only to the fulfillment of satisfying his needs but also to the approach and perspective to obtain and consume what is the necessities of his life.

Consumer behavior is the behavior exhibited by consumers in finding, buying, using, evaluating, and consuming products and services that they hope will satisfy their needs (Schiffman \& Kanuk, 2012: 54). Companies must be able to estimate what the needs and desires of customers by getting to know who their customers are and directing their business activities towards consumer-oriented.

Business performance can be identified properly through maximum marketing activities. The business world demands good performance through superior marketing and can meet company targets through aggregated sales. A consumer-oriented marketing strategy on the basis of well-known consumer behavior is to identify answers to questions such as what to buy, where to buy, how to buy habits and under what conditions goods and services are purchased. Based on this understanding the entrepreneur knows the motives of consumers directly or indirectly that has a great influence in as- 
sessing, perceiving a business that is in accordance with the concept that is in the minds of consumers in making an alternative sequence in making purchasing decisions.

Many factors will influence purchasing decisions made by a consumer. One factor that is expected to affect consumers is the location, promotion, and merchandising program conducted by a company. The better the location of a business unit and easily accessible to consumers, the greater the possibility that the business unit will experience a significant increase. Likewise in the case of promotion, if the business unit is more aggressively conducting promotional programs, it will certainly be more widely known by the community, which in the end the community will make a purchase decision on the product concerned. Another thing is related to merchandising carried out by the business unit. If the business unit can implement an attractive merchandising program, it will produce a good purchasing decision.

PT Wijaya Motor Bandung is one of the distributors of Toyota car products for the city of Bandung. This company has been widely known by the public as a credible company in selling Toyota car products. In order to create more significant sales from year to year, the company strives to find a strategic showroom location, ongoing promotional programs and merchandising that is as attractive as possible in order to increase high purchasing decisions.

Research Curhan (1974), Wanninayake \& Randiwela (2007), Anggraeni \& Nurcahya (2007), Muslim \& Mudiantono (2011), Kiran et al. (2012), Adji (2013), Widowati \& Purwanto (2014), Santi \& Kamal (2014), Sari \& Suryani (2014), found that location, promotion and merchandising had a positive and significant effect on consumer purchasing decisions. Therefore, the purpose of this study is to determine the effect of location, promotion and merchandising on consumer purchasing decisions at PT Wijaya Motor Bandung, Indonesia.

\section{B. LITERATURE REVIEW}

\section{The Location}

Location is one of the situational factors that influence the purchasing decision. In the marketing concept, there is a term known as marketing mix which consists of product, price, promotion, and place or business location. In this marketing mix, the business location can also be called the company's distribution channel because the location is also directly related to the buyer or consumer or in other words the location is also the place where the producers distribute their products to consumers. According to Mischitelli (2012: 10), location is a major component of the ability of a business sector to sell its products, so they can be sold easily. Meanwhile, according to Buchari Alma (2013: 103) stated that the location is where the company operates or where the company carries out activities to produce goods and services that are concerned with economic aspects. 
Location is the physical structure of a business that is a major component that is seen in shaping the impression of a business carried out by the company is placing its business and activities in providing service channels needed by consumers (Utami, 2012: 89). According to Heizer \& Render (2015: 19), location is a driver of costs and revenue, so location often has the power to make a company's business strategy. The strategic location aims to maximize profits from the company's new location.

Based on the above theory it can be concluded that a location is a place where the company operates and produces goods and services and the selection of a company location is crucial for the success of a business. According to Mischitelli (2012:12), the indicators of determining a good location are as follows:

a. Place, are matters relating to location and position. The location of a restaurant should be close to the center of the crowd or close to densely populated areas.

b. Parking, business premises should have their own parking space or use a large, comfortable and safe public parking area for both two-wheeled and fourwheeled vehicles.

c. Accessibility, the place of business should be on an easy road to reach it, both by private vehicles and by public transportation.

d. Visibility, the building of the place of business should be easily seen and known by many people.

e. Infrastructure, this section concerns the entire building where a place is already operating, for example, public facilities, transportation, and others.

\section{The Promotion}

Today's company considers that promotion is an important part of marketing because the company hopes that the promotion carried out effectively can improve the quality of the company's products or services in accordance with predetermined sales targets and can compete with other companies that produce similar products or services. With this view, the company hopes that by carrying out promotional activities on an ongoing and directed basis it will be able to achieve maximum sales and profit results.

According to Saladin and Oesman (2014: 123), promotion is a communication of information of sellers and buyers that aims to change attitudes and behavior of buyers, who previously did not know to be familiar to become buyers and remember the product. While the notion of promotion according to Alma (2013: 179), promotion is a kind of communication that gives an explanation and convinces prospective consumers about goods and services with the aim to get attention, educate, remind and convince potential customers. Promotion is a means of communication and delivery of messages carried out both by companies and intermediaries with the aim of providing information about products, prices, and places. That information is informing, persuading, reminding consumers, intermediaries or a combination of both. 
Sales promotion according to Tjiptono (2015: 229) is a form of direct persuasion through the intensive use of variables that can be arranged to stimulate product purchases immediately or increase the number of items purchased by customers.

Based on the opinions of the experts above, it can be concluded that promotion is a means of communication and delivery of messages carried out both by companies and intermediaries whose purpose is to convey information to consumers about products and prices sold. In addition to paying attention to promotional tools, companies must be able to choose the right promotional indicators in promoting products. According to Kotler and Keller (2012: 272), promotional indicators include:

a. Promotion frequency is the number of promotions carried out at a time through promotional media

b. Promotion quality is a measure of how well a sales promotion is done

c. Promotion quantity is the value or number of promotions given to consumers

d. Time of promotion is the length of promotion carried out by the company

e. Accuracy or appropriateness of promotional goals is a factor needed to achieve the desired target of the company.

\section{Merchandising}

The activities of retail traders or retailers include trade that sells products and services directly to consumers. Merchandise is a product that retailers sell to consumers in their outlets to consumers while merchandising can be interpreted as an effort to procure and handle goods (Sujana, 2013: 45). According to Ma'aruf (2012: 98) explains that merchandising is the procurement of goods in accordance with the business undertaken by the store (food-based products, clothing, home goods, general products, etc., or a combination) to be provided in shop at the appropriate amount, time and price to reach the target and the store or retail company. Merchandise is a product or service that is sold, and the buyer can give a good image if a store has a good quality product or service and if the store provides the goods the buyer wants, then the store must know the needs of consumers. This attribute is one of the attractions for consumers themselves (Sullivan \& Adcock, 2012: 32). According to Dunne, et. al cited by Foster (2013: 54) merchandise is planning and controlling in buying and selling goods and services to achieve the goals set by retailers. Merchandise is a group of products that are closely related to each other shown to the same consumer group or with the same price range.

Merchandise is a product that retailers sell to consumers in their outlets to consumers while merchandising can be interpreted as an effort to procure and handle goods (Sujana, 2012: 21). Furthermore, Davidson (in Sujana, 2012: 21) explains that the terminology of the 5 Right of merchandising is as follows:

a. Right Merchandise: means the type, model, brand, color, size, etc. that consumers want to buy. 
b. Right Place: refers not only to the location of the store but what goods should be in a store and a display place in the store and the place of display in the store itself.

c. Right Quantities: means that the existence of goods in quantities in accordance with consumer needs.

d. Right Time: This means that the presence of goods in the store at a time when consumers need it.

e. Right Price: is the level of the price of goods that are reasonable and compete at the level where it still benefits the retailer.

\section{Purchasing Decisions}

Purchasing decisions are part of consumer behavior. Where consumer behavior itself is the actions of individuals who are directly involved in evaluating businesses also obtain, use and determine products and services. Peter and Olson (2013), said that the core of consumer decision making is a process that combines knowledge to evaluate several alternative behaviors and choose one of them. The outcome of this process is a choice, which is presented cognitively as a desire to behave.

According to Kotler (2012:184) consumer purchasing decisions are the final consumer and household purchasing decisions of individuals who provide goods and services for personal consumption. Meanwhile, according to Tjiptono (2015:19), consumer purchasing decisions are the choice of one of two or more alternative choices. According to Shiffman \& Kanuk (2013:485), the purchase decision is the selection of two or more choices. In other words, alternative choices must be available to someone when making a decision. Every consumer makes various decisions about the search, purchase, use of various products and brands at any given period.

From the various sources above, it can be concluded that consumer purchasing decisions are the choice of one of several alternative solutions to the problem collected by a consumer and manifest with concrete follow-up. After the process, then the consumer can evaluate their choices and determine the attitude to be taken next. Hsu and Chang in Tjiptono (2015: 23) put forward indicators to measure purchasing decisions as follows:
a. The desire to use the product.
b. The desire to buy products.
c. Prioritize the purchase of a product.
d. Willingness to sacrifice (time, cost, energy) to get a product.

\section{RESEARCH METHOD}

This research uses descriptive and verification methods with a quantitative approach, because of the variables that will be examined in relation to and the aim is to provide a structured, factual and accurate picture of the facts and relationships between 
variables studied by location, promotion and merchandising of purchasing decisions in PT Wijaya Motor Bandung. The type of data in this study uses quantitative data sourced from the research questionnaire. Samples for the study were 118 consumers at PT Wijaya Motor Bandung taken using a simple random sampling technique. Analysis of the data used in this research is a simple linear regression analysis and multiple linear regression analysis.

\section{RESULTS AND DISCUSSION}

\section{Classical Assumption Testing}

A series of data analysis processes using path analysis include testing classic assumptions, regression analysis and coefficient of determination, simultaneous hypothesis testing (f-test), and partial (t-test). Some assumptions that must be met are the normality test, multicollinearity test, autocorrelation test, and heteroscedasticity test

In testing whether the data distribution is normal or not, the way to detect it is by using a statistical test with the Kolmogorov-Smirnov test. If the probability value obtained is greater than 0.05 , it can be concluded that the residuals in the regression model are normally distributed.

\section{Table 1 Data Normality Test Results}

One-Sample Kolmogorov-Smirnov Test

\begin{tabular}{|c|c|c|}
\hline & & $\begin{array}{c}\text { Unstandardized } \\
\text { Residual }\end{array}$ \\
\hline $\mathrm{N}$ & & 118 \\
\hline \multirow[t]{2}{*}{ Normal Parameters ${ }^{a, b}$} & Mean & .0000000 \\
\hline & Std. Deviation & 1.63515675 \\
\hline \multirow[t]{3}{*}{ Most Extreme Differences } & Absolute & .071 \\
\hline & Positive & .037 \\
\hline & Negative & -.071 \\
\hline Test Statistic & & .071 \\
\hline Asymp. Sig. (2-tailed) & & $200^{\mathrm{c}, \mathrm{d}}$ \\
\hline
\end{tabular}

Based on the Kolmogorov Smirnov test it appears that the significance value of 0.2 is greater than 0.05 . Then it can be concluded that the data is normally distributed. In detecting multicollinearity problems can be seen from the VIF value. If the VIF value is less than 10, it can be concluded that the model is free from multicollinearity problems. 


\section{Table 2 Multicorelierity Test Results}

\begin{tabular}{|ll|r|r|}
\hline \multirow{2}{*}{\multicolumn{2}{|c|}{}} & \multicolumn{2}{|c|}{ Collinearity Statistics } \\
\cline { 3 - 4 } Model & Tolerance & \multicolumn{1}{c|}{ VIF } \\
\hline 1 & (Constant) & & \\
& X1 & .208 & 4.818 \\
& X2 & .243 & 4.121 \\
& X3 & .259 & 3.860 \\
\hline
\end{tabular}

Based on the table above, it can be seen that the VIF value for each variable is less than 10. These results indicate that there is no problem with multicollinearity between independent variables in the model.

The heteroscedasticity test aims to test the homogeneity of residual variance in a regression model. One way to detect heteroscedasticity is to look at the scatterplot graph between the predicted value of the dependent variable (ZPRED) and the residual value (SRESID).

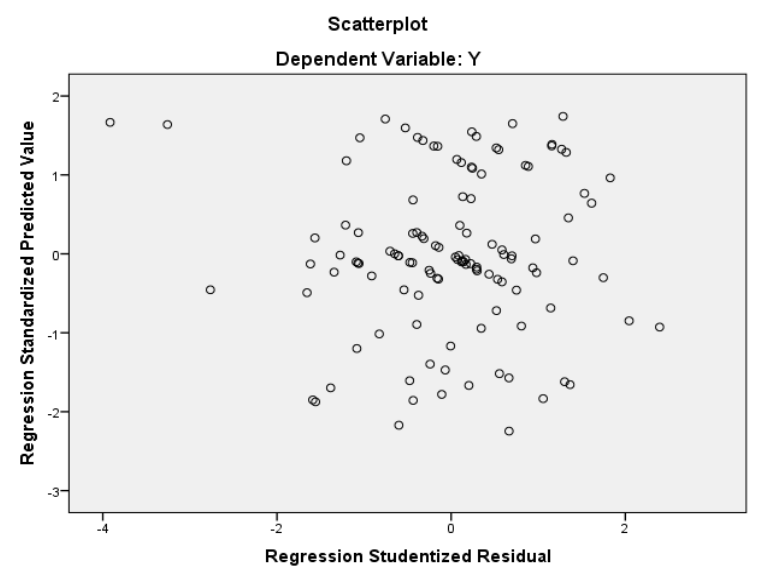

Figure 1 Heteroscedasticity Test Results

From the picture above it can be seen that in the model there is no heteroscedasticity because in the picture there is no clear pattern, and the points spread above and below the number 0 on the Y-axis. This indicates that in the model, the variance from one observation residual to another observation same or constant. So the assumption of the absence of heteroscedasticity or the presence of homoscedasticity has been fulfilled for the regression equation.

Autocorrelation test is used to determine whether or not there is a deviation from the classic assumption of autocorrelation, which is the correlation that occurs between residuals in one observation with other observations in the model. 


\section{Table 3 Autocorrelation Test Results}

\begin{tabular}{|l|r|r|r|r|r|}
\hline & & & \multicolumn{1}{c|}{ Model Summary } \\
Model & $\mathrm{R}$ & $\mathrm{R}$ Squared R & \multicolumn{1}{c|}{$\begin{array}{c}\text { Std. Error of the } \\
\text { Square }\end{array}$} & \\
\hline 1 & $.844^{\mathrm{a}}$ & .713 & .706 & 1.65653 & Dstimate \\
\hline
\end{tabular}

a. Predictors: (Constant), X3, X2, X1

b. Dependent Variable: $Y$

Based on Table 2 above, it is found that DW $=2,294$, with a level of $5 \%$ and $n=$ 118 , a dU value of 1.65 is obtained. Based on the decision making stated previously, it is obtained dU $(1.65)<\mathrm{DW}(2,294)<4-\mathrm{dU}(2.36)$, it can be concluded that there is no autocorrelation in the model.

\section{Regression Analysis}

Because the results of this study have fulfilled the four assumptions above, the regression model that was formed has produced estimates that meet the BLUE (best linear unbiased estimated) criteria. By using SPSS program application, the output of multiple linear regression calculation results is obtained as follows:

Table 4 Results of Regression Analysis

\begin{tabular}{|ll|r|r|r|r|}
\hline \multirow{2}{*}{ Model } & & \multicolumn{2}{|c|}{ Unstandardized Coefficients } & \multirow{2}{*}{} \\
\cline { 3 - 4 } 1 & $\mathrm{~B}$ & Std. Error & \multicolumn{1}{c|}{$\mathrm{t}$} & \multicolumn{1}{c|}{ Sig. } \\
\hline \multirow{2}{*}{1} & (Constant) & .587 & .761 & .772 & .442 \\
& X1 & .268 & .090 & 2.986 & .003 \\
& X2 & .267 & .082 & 3.254 & .001 \\
& X3 & .194 & .082 & 2.368 & .020 \\
\hline
\end{tabular}

Value of constants and regression coefficients so that multiple linear regression equations can be formed as follows: $\mathrm{Y}=0.587+0.268 \mathrm{X} 1+0.267 \mathrm{X} 2+0.194 \mathrm{X} 3$. The equation of the multiple regression analysis presented above can be explained as follows:

a. A constant of 0.587 shows the average score of the Judgment Decision if the Teacher's Location, promotion, and merchandising scores are zero.

b. Regression coefficient for the Location variable $(X 1)$ is 0.268 which shows the magnitude of the change in the average score of Purchasing Decisions that are influenced by Location, a positive sign indicates the influence that occurs is unidirectional meaning that each score increases in the Location variable by 1 unit and other variables are considered constant, then the Purchasing Decision is predicted to increase by 0.268 units

c. Regression coefficient for the Promotion variable (X2) is 0.267 which shows the magnitude of the change in the average score of Purchasing Decisions influenced by Merchandising, a positive sign indicates the influence that occurs is 
unidirectional meaning that every increase in the Merchandising variable is 1 unit and the other variables are considered constant, then the Purchasing Decision is predicted to increase by 0.267 units.

d. The regression coefficient for the Merchandising variable (X3) is 0.194 which shows the average change in the score of the Purchasing Decision which is influenced by Merchandising, a positive sign indicating the effect that occurs is unidirectional meaning that every increase in the Merchandising variable is 1 unit and the other variables are considered constant, then the Purchasing Decision is predicted to increase by 0.194 units.

\section{Analysis of the Coefficient of Determination}

The coefficient of determination (R2) aims to measure how far the model's ability to explain the variation of the dependent variable. A value of $\mathrm{R} 2$ close to one means that the independent variables provide almost all the information needed to predict the variation of the dependent variable (Ghozali, 2005).

\section{Table 5 Analysis of the Coefficient of Determination}

\begin{tabular}{|l|r|r|r|r|r|}
\hline & & & Model Summary \\
Model & $\mathrm{R}$ & $\mathrm{R}$ Square & \multicolumn{1}{c|}{$\begin{array}{c}\text { Adjusted R } \\
\text { Square }\end{array}$} & $\begin{array}{c}\text { Std. Error of the } \\
\text { Estimate }\end{array}$ & Durbin-Watson \\
\hline 1 & $.844^{\mathrm{a}}$ & .713 & .706 & 1.65653 & 2.294 \\
\hline
\end{tabular}

a. Predictors: (Constant), X3, X2, X1

b. Dependent Variable: $Y$

Based on the table above it appears that the calculation results obtained Adjusted $\mathrm{R}$ Square (R2) value of 0.713 , in other words, it shows that the percentage of Purchase Decision variations that can be explained by variations of the three independent variables namely Location, Promotion and Merchandising is $71.3 \%$, while the remaining $28.7 \%$ is explained by other causes outside the model.

To find out the coefficient of determination partially between location variables, promotion and merchandising of purchasing decisions can be seen through the following table:

Table 6 Beta and Zero-Order Coefficient Values

\begin{tabular}{|ll|r|r|r|r|}
\hline & & \multicolumn{1}{|c|}{$\begin{array}{c}\text { Standardized } \\
\text { Coefficients }\end{array}$} & \multicolumn{3}{|c|}{ Correlations } \\
\cline { 3 - 6 } Model & Beta & Zero-order & \multicolumn{1}{|c|}{ Partial } & \multicolumn{1}{c|}{ Part } \\
\hline 1 & (Constant) & & & & \\
& X1 & .329 & .808 & .269 & .150 \\
& X2 & .331 & .801 & .292 & .163 \\
& X3 & .233 & .779 & .216 & .119 \\
\hline
\end{tabular}


From the calculation above, it is known that the magnitude of the influence of location on purchasing decisions is $26.6 \%$, promotion of purchasing decisions is $26.5 \%$ while the magnitude of the influence of merchandising on purchasing decisions is 26.6 $\% \%$. This shows that location and promotion variables have influence values that are not much different, so location and promotion have a greater influence on purchasing decisions.

\section{Hypothesis Test}

The results of testing the first hypothesis location for purchasing decisions obtained sig. $(0.003)<0.05$ so $\mathrm{H} 0$ is rejected which means that Location has a positive and significant effect on Purchasing Decisions at PT Wijaya Motor Bandung, with a positive direction indicating that the better the location will have an impact on higher purchasing decisions and vice versa the more unfavorable location then will have an impact on purchasing decisions that are lower too.

The results of testing the second hypothesis of the promotion of the purchasing decision obtained sig. $(0.001)<0.05$ so $\mathrm{H0}$ is rejected, which means that promotion has a positive and significant effect on purchasing decisions at PT Wijaya Motor Bandung, with a positive direction indicating that the better the promotion will have an impact on higher purchasing decisions and vice versa the less good the promotion then will have an impact on purchasing decisions that are lower too.

The results of testing the third hypothesis of merchandising on purchasing decisions obtained sig. $(0.020)<0.05$ so $\mathrm{HO}$ is rejected, which means that merchandising has a positive and significant effect on purchasing decisions at PT Wijaya Motor Bandung, with a positive direction indicating that the better the merchandising will have an impact on higher purchasing decisions and vice versa the less good the Merchandising will have an impact on purchasing decisions that are lower too.

The fourth hypothesis testing results namely testing simultaneously obtained location, promotion and merchandising of purchasing decisions, obtained sig. $(0,000)$ $<0.05$ so that $\mathrm{H} 0$ is rejected, which means that location, promotion and merchandising have a significant effect on procurement decisions at PT Wijaya Motor Bandung.

\section{CONCLUSION}

Based on the results of the study note that there is an influence between location, promotion and merchandising on purchasing decisions at PT Wijaya Motor Bandung, both partially and simultaneously. There is a significant influence between Location on Purchasing Decisions at PT Wijaya Motor Bandung, with a large influence of 26.6\%. There is a significant influence between Promotion of Purchasing Decisions at PT Wijaya Motor Bandung, with a large influence of $26.5 \%$. There is a significant influence between merchandising on purchasing decisions at PT Wijaya Motor Bandung, with an influence of $18.2 \%$. There is a significant influence between Location, promotion and 
merchandising together on Purchasing Decisions at PT Wijaya Motor Bandung. Location, promotion and merchandising influence $71.3 \%$ of the Purchasing Decision at PT Wijaya Motor Bandung, while the remaining 28.7\% is influenced by other variables outside the known model.

\section{REFERENCES}

1. Adji, P. (2013). Pengaruh Retail Mix Terhadap Keputusan Pembelian Mahasiswa UK Petra Di Circle K Siwalankerto Surabaya. Jurnal Strategi Pemasaran, 1(2), 1-10.

2. Alma, B. (2013). Manajemen Pemasaran dan Pemasaran Jasa. Bandung: Alfabeta.

3. Anggraeni, D. T., \& Nurcahya, I. K. (2007). Pengaruh Retail Mix Terhadap Keputusan Pembelian Pada Bali Cenik Kids Apparel di Denpasar. E-Jurnal Manajemen, 3(9).

4. Curhan, R. C. (1974). The effects of merchandising and temporary promotional activities on the sales of fresh fruits and vegetables in supermarkets. Journal of Marketing Research, 11(3), 286-294.

5. Foster, B. (2013). Manajemen Ritel. Bandung: Alfabeta.

6. Ghozali, I. (2005). Aplikasi Analisis Multivariate dengan SPSS. Semarang: UNDIP.

7. Gujarati, D. (2003). Ekonometrika Dasar. Jakarta: Erlangga.

8. Heizer, J., \& Render, B. (2015). Manajemen Operasi. Jakarta: Salemba Empat.

9. Kiran, V., Majumdar, M., \& Kishore, K. (2012). Innovation in in-store promotions: effects on consumer purchase decision. European Journal of Business and Management, 4(9).

10. Kotler, P. \& Keller, K.L. (2012). Manajemen Pemasaran Jilid I. Jakarta: Erlangga.

11. Kotler, P. (2012). Manajemen Pemasaran 1 dan 2. Jakarta: Prenhallindo.

12. Ma'ruf, H. (2012). Pemasaran Ritel. Jakarta: Gramedia Pustaka Utama.

13. Mischitelli, V. (2012). Your New Restaurant. Canada: Adams Media Corporation.

14. Muslim, M. I., \& Mudiantono, M. (2011). Analisis Pengaruh Merchandise, Promosi, Atmosfir Dalam Gerai, Pelayanan Ritel, Dan Harga Terhadap Keputusan Pembelian (Studi

Kasus Pada Toko Buku Gramedia Pandanaran Kota Semarang) (Doctoral dissertation, Universitas Diponegoro).

15. Peter, J. P., \& Olson, J. C. 2013. Perilaku Konsumen dan Strategi Pemasaran. Jakarta: Erlangga.

16. Saladin, D., \& Oesman, Y. M. (2014). Intisari Pemasaran dan Unsur-unsur Pemasaran. Bandung: Linda Karya.

17. Santi, D. E., \& Kamal, M. (2014). Analisis Pengaruh Produk, Lokasi, Promosi Dan Kualitas Pelayanan Terhadap Keputusan Pembelian Produk Merchandise (Studi Pada Mandiri Art, Tembalang Semarang) (Doctoral dissertation, Fakultas Ekonomika dan Bisnis). 
18. Sari, D. A. T., \& Suryani, A. (2014). Pengaruh Merchandising, Promosi dan Atmosfir Toko Terhadap Impulse Buying. E-Jurnal Manajemen, 3(4).

19. Schiffman, I. G. \& Kanuk, L. L. 2013. Consumer Behavior. New Jersey: Prentice Hall.

20. Sekaran, U. (2012). Research Methods for Business. Jakarta: Salemba Empat.

21. Sujana, A. E. (2013). Pengaruh Labelisasi Halal Terhadap Keputusan Pembelian Konsumen. Jurnal Ilmiah Manajemen Kesatuan, 1(2).

22. Sullivan, M., \& Adcock, D. 2012. Retail Marketing (1st ed.). London: Thomson.

23. Tjiptono, F. (2015). Strategi Pemasaran. Yogyakarta: Andi Offset.

24. Utami, C. W. (2012). Manajemen Ritel. Jakarta: Salemba Empat.

25. Wanninayake, W. M. C. B., \& Randiwela, P. (2007, October). The impact of visual merchandising on consumer store choice decisions in Sri Lankan supermarkets. In 7th Global conference on Business E Economics (Vol. 10, pp. 13-14).

26. Widowati, M., \& Purwanto, A. B. (2014). Pengaruh Kualitas Pelayanan Dan Lokasi Terhadap Keputusan Pembelian Dengan Visual Merchandising Sebagai Variabel Moderating. Fokus Ekonomi: Jurnal Ilmiah Ekonomi, 9(1). 